\title{
Effects of Organic and Inorganic Fertilizers on the Yield Components of NH-Ae 47-4 Variety of Okra
}

\section{*11MOLIK, A. ZAINAB, ELUWA, C. VINCENT; OLUWATOBI, S. AYODELE LAKWANNUM, GAYUS Y; OLORUNMAIYE, S. KEHINDE}

\author{
Department of Plant Biology, Faculty of Life Sciences, University of Ilorin, PMB 1515, Ilorin, Nigeria. \\ Corresponding author: ayodeleoluwatobi@gmail.com ${ }^{*},+2347064987030^{*}$ \\ ksolorunmaiye@yahoo.com
}

\begin{abstract}
The experiment was carried out to evaluate the effects of organic and inorganic fertilizers on the yield components of okra (variety NH-Ae 47-4). Organic fertilizers (cow dung and poultry droppings) and inorganic (NPK 15:15:15 and Urea 64:0) fertilizers were used for the experiment. The fertilizers were weighed and applied at $5 \mathrm{~g}, 10 \mathrm{~g}$ and $15 \mathrm{~g}$ and were replicated three times and each having a control. The fertilizers were mixed three days prior to sowing the seeds. Yield components taken include; fresh pod weight $(\mathrm{g})$, dry pod weight $(\mathrm{g})$, length of pod $(\mathrm{cm})$, number of grooves on the pod, length of stalk $(\mathrm{cm})$ and pod girth $(\mathrm{cm})$. Application of cow dung, poultry litter, and urea and NPK fertilizer had significant effects on all the parameters accessed with Urea fertilizer having least effect. The application of cow dung resulted in significant increase in the yield components. The results obtained from the experiment also showed that the effect of the treatments were significantly difference from the control. (C) JASEM
\end{abstract}

KEYWORDS: evaluate, cow-dung, poultry-droppings, okra, yield.

\section{Introduction}

Okra (Abelmoschus esculentus Moench) is an annual, herbaceous flowering plant in the Mallow family that originated from tropical and subtropical Africa and is natural to the West Africa (Aladele et al., 2008). Okra is mainly cultivated for its young immature fruits and consumed as a vegetable, raw, cooked or fried in countries like Sudan, Egypt and Nigeria; it is also important in other tropical areas including Asia central and South America often used as ingredient of soups and sauces. The fruits can be conserved by drying or pickling, the roasted seed is considered as coffee substitute; the leaves, flower buds, flowers and calyces can be eaten cooked as greens (Ajari et al., 2003). In Nigeria, okra is grown in both wet and dry season but attract a larger profit in the dry season when the demand is often in excess with limited supplies (Ayeni et al., 2012). Okra is a good source of vitamins, minerals, calories and amino acid found in seeds and compares favorably with those in poultry, eggs and soybean (Brady and Weil, 1999).

Okra cultivation requires nutrients such as nitrogen $(\mathrm{N})$, phosphorus $(\mathrm{P})$, potassium $(\mathrm{K})$, calcium $(\mathrm{Ca})$, sodium (Na) and Sulphur (S) for fertility maintenance and crop production. These nutrients are specific in function and must be supplied to plants at the right time and at the right quantity. Lack of sufficient amounts of these nutrients result in poor performance of the okra with growth been affected resulting to low yield (Chauhan, 1972). In developing countries like
Nigeria, the population growth rate is so high that improved technologies including rational use of fertilizers must be employed to meet the food requirement of the people (Hedrick, 1972). Improving soil fertility through the application of fertilizers is an essential factor enabling the world to feed the billions of people that are added to its population (Hera, 1996). Declining soil fertility is a major production constraint in Africa, especially in Nigeria, and it is becoming increasingly critical to secure sustainable soil productivity (Massomo and Rweyemamu, 1989; Oladotun, 2002). Organic manure helps to improve the physical condition of soil and provide adequate amount of necessary nutrients for the soil productivity (Qhureshi, 2007).

Thus there is a need for cultivation of okra with increased yield and quality, which this present study is aimed at investigating which of the following fertilizer application; organic (Poultry litter, cow dung) and inorganic (NPK 15:15:15: and Urea 64:0) fertilizer will have more effect on the yield components of okra (Abelmoschus esculentus).

\section{MATERIALS AND METHODS}

The study was carried out between January 2014April 2014 at the Agricultural Research site of the faculty of Agriculture in the University of Ilorin, Ilorin Nigeria. The variety of okra (Abelmoschus esculentus Moench) used was NH Ae 47-4. The 
materials used in carrying out this experimental work includes; Cow dung, poultry litter, NPK (15: 15: 15), Urea fertilizer (46: 0: 0), weighing balance, petridishes and spatula, watering balance, hoe, thread, potting buckets, hand shovel, sandy-loamy topsoil, meter-rule, tape rule, foil paper, oven and writing materials.

Forty-eight plastic buckets (five-litre capacity each), viable seeds of $\mathrm{NH}$ Ae 47-4 varieties of okra, inorganic fertilizers (NPK 15:15:15 and Urea 46:0:0), organic fertilizers (cow dung and poultry litters) were used for the experiment.

Each of the buckets was perforated and filled with sandy-loam soil. Each of the fertilizers weighing $5 \mathrm{~g}$, $10 \mathrm{~g}$ and $15 \mathrm{~g}$ replicated three times was mixed with the soil in the buckets each having a control (i.e. without fertilizer). The cow dung and poultry litter was ground into a powdery form and sieved prior to weighing and mixing with the soil. The fertilizers were mixed 3days prior to sowing the seeds.
Germination ranged between 4 to 7 days and germination count was taken after a week. Ample watering was done to avoid rotting of the seedlings. Seeds were re-sown in buckets which had no germination. Measurement of growth parameters commenced 3 weeks after planting with careful hand weeding to avoid pest and nutrient competition. Data were collected 3 weeks after planting (WAP) and at weekly intervals thereafter. The parameters taken after harvest include; fresh pod weight $(\mathrm{g})$, dry pod weight $(\mathrm{g})$ length of pod $(\mathrm{cm})$, number of grooves on the pod, length of stalk $(\mathrm{cm})$, pod girth $(\mathrm{cm})$.

\section{RESULTS AND DISCUSSION}

Generally, organic manure favoured the yield of $\mathrm{NH}$ Ae 47-4 variety of okra than inorganic fertilizers. Poultry litter favoured higher fruit number while cow dung favours the other fruit characteristics with urea fertilizer having the least effect. The results are represented in Table 1.

Table 1: Effects of Cow dung, Poultry litter, NPK and Urea fertilizers on yield of NH Ae 47-4.

\begin{tabular}{|c|c|c|c|c|c|c|c|}
\hline Treatment (g) & Fruit number & $\begin{array}{c}\text { Av.fresh pod } \\
\text { weight (g) } \\
\end{array}$ & $\begin{array}{c}\text { Av. dry pod } \\
\text { weight (g) }\end{array}$ & $\begin{array}{c}\text { Av.pod length } \\
(\mathrm{cm})\end{array}$ & $\begin{array}{c}\text { Av.groove } \\
\text { number }\end{array}$ & $\begin{array}{l}\text { Av. Length } \\
\text { of stalk (cm) }\end{array}$ & $\begin{array}{c}\text { Av. pod } \\
\text { girth }(\mathrm{cm})\end{array}$ \\
\hline $\begin{array}{ll}\text { Cow dung } & 0\end{array}$ & 4 & 5.26 & 0.48 & 6.43 & 6.25 & 1.05 & 5.07 \\
\hline 5 & 4 & 8.31 & 0.86 & 8.03 & 6.75 & 1.38 & 5.34 \\
\hline 10 & 6 & 6.86 & 0.76 & 6.25 & 7.33 & 1.17 & 5.83 \\
\hline 15 & 7 & 7.72 & 0.69 & 6.73 & 7.71 & 1.46 & 5.31 \\
\hline Poultry litter 0 & 4 & 4.33 & 0.45 & 5.52 & 6.00 & 1.25 & 4.14 \\
\hline 5 & 8 & 5.93 & 0.55 & 5.95 & 6.63 & 1.25 & 4.46 \\
\hline 10 & 10 & 7.01 & 0.61 & 7.49 & 7.20 & 1.46 & 5.11 \\
\hline 15 & 13 & 6.58 & 1.11 & 7.58 & 7.38 & 1.41 & 4.60 \\
\hline NPK fertilizer 0 & 6 & 4.97 & 0.44 & 6.08 & 6.67 & 1.28 & 4.23 \\
\hline 5 & 3 & 4.53 & 0.51 & 5.53 & 6.67 & 1.37 & 4.43 \\
\hline 10 & 2 & 4.40 & 1.17 & 5.70 & 6.50 & 0.95 & 4.30 \\
\hline 15 & 2 & 3.50 & 0.35 & 5.20 & 5.50 & 1.30 & 4.15 \\
\hline Urea fertilizer 0 & 5 & 5.16 & 0.48 & 6.48 & 7.2 & 1.42 & 4.40 \\
\hline 5 & 1 & 6.27 & 0.47 & 6.90 & 7.00 & 1.40 & 5.00 \\
\hline 10 & 0 & 0.00 & 0.00 & 0.00 & 0.00 & 0.00 & 0.00 \\
\hline 15 & 0 & 0.00 & 0.00 & 0.00 & 0.00 & 0.00 & 0.00 \\
\hline
\end{tabular}

Optimum crop performance is usually limited by inadequate availability of essential nutrients. The results of this research highlighted the superiority of fertilized plants over non-fertilized and poorly fertilized (urea) ones in term of growth. The consistently poor performance of non-fertilized plants shows that when nutrients are available in adequate amount there is tendency for plants to produce at their optimum potential. The experiment reveals that NPK fertilizer; poultry litter and cow dung application significantly influenced the growth of the $\mathrm{NH}-\mathrm{Ae}$ 47-4 variety of okra.

Ayeni et al. (2012) stated that poultry litter and cow dung contains useful soil nutrients that are needed for the growth and of plants, but their composition is in the crude form that is released slowly to the soil.
Fruit/pod number per plants was highest with poultry manure however the overall fruit characteristics were lower with poultry litter, NPK and urea compared to cow dung due to the vegetative growth that has been favored more. The fruit characteristics include; average fresh and dry pod weight, average pod length, average groove number, average stalk length and average pod girth. Cow dung contained higher Nitrogen but they seemed not to be released early enough to compare with poultry manure and NPK.

The fruit yield was favored by organic manure (poultry and cow dung) than inorganic fertilizer (NPK and Urea). This was in accordance with Oladotun (2005) and Xu et al. (2005) who in a study on yield and quality of leafy vegetables grown with organic fertilizers showed that vegetables grown with organic fertilizers grew better and resulted in a higher 
total yield than those grown with chemical fertilizers. Therefore, this study suggested that vegetables grown with organic fertilizers showed higher growth and yield than those grown with inorganic fertilizers.

Conclusion: The application of poultry litter, cow dung, NPK fertilizer and urea fertilizer had a significant effect on the yield and yield components of NH Ae 47-4 variety of okra. The results obtained revealed that this variety responded well to the application of organic manure compared to inorganic fertilizer and control treatment in the study. Based on the findings of this study, it may be recommended that applying organic manure was adequate for maximum growth and yield of $\mathrm{NH} \mathrm{Ae}$ 47-4 variety of okra and inorganic fertilizers especially NPK fertilizer may be applied in the absence of organic manure.

\section{REFERENCES}

Aladele, S.E., Ariyo, O.J. and Lapena, R. (2008). Genetic Relationship among West African Okra (Abelmoschus caillei) and Asian genotypes (Abelmoschus esculentus) using RAPD. African Journal Biotechnology, 7: 1426-143.

Ajari, O., Tsado, L. E. K., Oladiran, J. A. and Salako, E. A. (2003). Plant height and fruit yield of okra as affected by field application of fertilizer and organic matter in Bida, Nigeria. The Nigerian Agricultural Journal, 34: 74 - 80.

Ayeni, L. S., Adeleye, E, O. and Adejumo, J. O. (2012). Comparative effect of organic, organomineral and mineral fertilizers on soil properties, nutrient uptake, growth and yield of Maize (Zea mays). International Research Journal of Agricultural Science and Soil Science, 2(11):493-497.

Brady, N.C. and Weil, R. (1999). The Nature and Properties of soil. 12th Edition. Mac. Pub. Com. New York. 625-640.

Chauhan, D. V. S. (1972). Vegetable Production in India (3rd edition). Ram Prasad and Sons, Agra.
Hedrick, U. P. (1972). Sturtevant's Edible Plants of the World. Dover Publications.

Hera, C. (1996). Role of Inorganic fertilizer and their management practices. Kluwer Academic Publishers Fert. Res. 43:63-81

Massomo, S. M. S. and Rweyemamu, C. L. (1989). Evaluation of the effects of cattle and poultry manure in combination with inorganic $\mathrm{N}$ fertilizer on seed yield, yield components and seed quality of common bean ( $P$. vulgaris L.) grown in different plant stands per hill. In: Bean Research. Maeda and Nchimbi (Eds.). 4: 88-98.

Oladotun, A.O., (2002). Managing manure as a fertilizer; Saskatchewani, Agriculture, Food and Rural Revitalization, pp. 5.

Qhureshi, Z. (2007). Breeding Investigation in Bhendi (Abelmoschus esculentus (L.) Moench). Master Thesis, University of Agriculture Sciences, GKVK, Bangalore.

Sanchaz, P. A., Shapher, K. D., Soul, M. J., Place, E. M., Momwunyea, A. U., Buresh, R. J., Kwesiga, F.R., Izac, A. M., Nderitu, C. G. and Woomer, P. L. (1997). Soil fertility replenishment in Africa: an investment in natural resource capital in: replenishing soil fertility in Africa,Eds.

Shukla, V.and Nalk, L. B. (1993). Agro-Technique for Malvaceae Vegetables, In: Ifovance in horticulture vol 5. Malhotra publishing house, New Delhi, India, pp 399-425.

Tindall, H. D. and Rice, R. P. (1983). Fruit and Vegetable Production in Warm Climates. The Macmillan press Ltd Nigeria. $85 \mathrm{pp}$.

Varmudy, V. (2011). Marking survey need to boost okra exports. Department of economics, Vivekananda College, Puttur, Karnataka, India. 